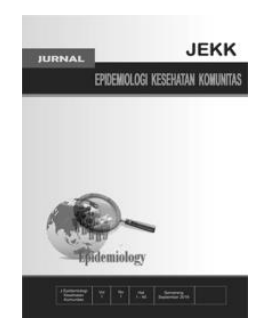

\title{
Antibacterial Activity From Temulawak Extract (Curcuma xanthorrhiza Roxb) On Growth Inhibition of Staphylococcus epidermidis In Vitro
}

\author{
Ni Wayan Mutiara Warmasari*, Desak Ketut Ernawati**, Agung Wiwiek Indrayani**, Ni Wayan Sucindra \\ Dewi $^{* *}$, I Made Jawi** \\ *Student of Medicine and Medical Doctor Profession Education, Faculty of Medicine, Udayana University, \\ Denpasar, Bali, **Pharmacology and Therapy Department, Faculty of Medicine, Udayana University,
} Denpasar, Bali

\begin{abstract}
Background: Infection is the main causes of disease in tropical regions like Indonesia. Staphylococcus epidermidis is an opportunistic bacterium that attacks when the body's immune system is weak. The incidence of bacterial resistance to antibiotics already exists, so that it requires an alternative treatment. One of potential alternative treatment is the use of temulawak rhizome extract (Curcuma xanthorrhiza Roxb). Temulawak rhizome extract have a variety of chemical contents as active compounds in the form of essential oils, for example xanthorrhizol and curcumin, which can affect the rate of bacterial growth.

Methods: This study aimed to determine the antibacterial activity of temulawak rhizome extract on the growth of Staphylococcus epidermidis bacteria in vitro. The method used in this study is the true experimental with post-test only control group design. Samples were divided into four treatment concentrations such as the extract concentration of $25 \%, 50 \%, 75 \%$, and $100 \%$ of temulawak rhizome, which was tested by agar diffusion method (Kirby-Bauer).

Result: The results of the analyze of variant (ANOVA) test showed a significant difference in various concentrations of the temulawak rhizome extract $(p=0,000)$. The temulawak extract could inhibit bacterial growth with a medium inhibitory response $(5-10 \mathrm{~mm})$. Temulawak rhizome extract showed the greatest inhibition at $100 \%$ concentration with an average inhibition zone diameter of $9.20 \mathrm{~mm}$.

Conclusion: The extract of temulawak rhizome has antibacterial activity. It can be concluded that the higher concentration of temulawak rhizome extract (Curcuma xanthorrhiza Roxb), the greater ability to inhibit the growth of Staphylococcus epidermidis bacteria.
\end{abstract}

Keywords: Antibacterial; Curcuma xanthorrhiza Roxb; Staphylococcus epidermidis; in vitro; growth inhibition

\footnotetext{
*Coresponding author, mutyaraw@gmail.com
} 


\section{Introduction}

Infection is one of the main causes of disease in tropical regions like Indonesia. Infectious diseases can be caused by various microorganisms such as bacteria, fungi, viruses, and parasites. ${ }^{1}$ One of the grampositive bacteria that can cause infections in the human body is the Staphylococcus epidermidis. Staphylococcus epidermidis is an opportunistic bacterium that attacks individuals when the body's immune system is weak. Generally, this bacterium is found in acne or acne lesions, causing nosocomial infections in the joints and blood vessels as well as causing mild skin infections that can be accompanied by abscesses. ${ }^{2}$

Staphylococcus epidemidis bacteria can produce toxins or poisons as well as glycocalyx or mucus which makes it easy for bacteria to stick to and trigger infections in the human body. This mucus or glycocalyx also causes Staphylococcus epidemidis to have resistance to certain phagocytosis and antibiotics. ${ }^{3}$ Thus, in dealing with infections by the bacterium Staphylococcus epidermidis triggers researchers to look for alternative treatments that could be made a safe choice for consumption by the public. Treatment of infectious diseases can be treated with several plants that have antibacterial properties, one of which is the Curcuma xanthorrhiza Roxb plant or better known as temulawak. ${ }^{4}$

Temulawak is one of the spices in the form of rhizomes which is widely used as traditional medicine in the community. Society tends to use temulawak rhizome in treating intestinal diseases, liver disorders, constipation, fever in children, hypotriglycerides, hemorrhoids, appetite enhancer, relieve stomach ulcers, dysentery, and diarrhea, mouth ulcers and help clean the face of pathogenic bacteria that cause acne. $^{5}$

The main content of temulawak consists of starch, fiber, essential oils such as phellandrene, camphor or tumerol, sineol, borneol, and xanthorrhizol, and there are also active compounds of curcuminoids such as curcumin and desmetoxy curcumin. One content of temulawak rhizome that is not found in other types of Curcuma is curcumin and active xanthorrhizol essential oils which were reported in previous studies to have antibacterial, antiseptic, and antibiotic activity. ${ }^{6}$

\section{Methods}

The temulawak sample used follows the inclusion and exclusion criteria. Temulawak rhizome taken from temulawak plantations in Banjar Tebuana, Taro Village, Gianyar Regency with adult temulawak rhizomes and ready to harvest which is around 7-9 months after planting, the outside is brownish and the inside is yellowish red-orange. Whereas the temulawak rhizome which is young or less than 5 months old, not fresh, not intact and infected with the disease was not used in this study.

The tools used in this study are blenders, glass beakers, stirring rods, analytical scales, aluminum foil, filter paper, measuring cups, rotary evaporators, steam baths, electric stoves, test tubes and racks, ose, spiritus lamps, incubators, sticky cotton sterile, tweezers, calipers, petri dishes, Erlenmeyer tubes, tongs, micropipettes, autoclaves, blue tips, yellow tips, and paper discs.

The material used in this study used temulawak rhizome, ethanol $96 \%$, pure culture of Staphylococcus epidermidis ATCC 12228, vancomycin $30 \mu \mathrm{g}$, Muller Hinton (MH), aqua dest, Mc Farland solution 0.5, antibiotic discs and blank disc.

This study is an experimental study to determine the effect of temulawak rhizome extract (Curcuma xanthorrhiza Roxb) in inhibiting the growth of Staphylococcus epidermidis bacteria in vitro by using the true experimental post test only control group design method. ${ }^{8}$ This study was divided into two groups, the control group $(\mathrm{K})$ and the treatment group $(\mathrm{P})$. The control group was negative control (K1) and positive control was the antibiotic vancomycin in Staphylococcus epidermidis (K2) isolates while the treatment group was divided into 4 groups based on the dosage of the use of temulawak rhizome extract (Curcuma xanthorrhiza Roxb) on each Staphylococcus epidermidis isolate with $25 \%$ (P1), 50\% (P2), 75\% (P3) and 100\% (P4). This research was conducted at the Laboratory of Agricultural Technology and Microbiology 
Laboratory of the Faculty of Medicine, Udayana University.

This research was carried out with the following steps.

\section{Processing of Temulawak Extract}

Making ethanol extract of temulawak rhizome by maceration method. As much as 2 $\mathrm{kg}$ of temulawak rhizome is washed with running water, dried for 2 hours and thinly sliced with a diameter of $7 \mathrm{~mm}-8 \mathrm{~mm}$. Furthermore, drying is done by leaving it at room temperature or in an oven at $50^{\circ} \mathrm{C}$. Dried temulawak rhizome and then blended and sifted to obtain 300 grams of fine powder. Then the temulawak rhizome powder was dissolved with $96 \%$ ethanol solution in a ratio of 1:10 times simplist ie $3000 \mathrm{ml}$ and allowed to be macerated for 24 hours in a macerator with stirring every 1 hour. After that, maserat filtered using filter paper. The remaining deposits in the maserator are macerated for 24 hours. The filtrate from the first and second maceration results are mixed and then put into a rotary evaporator at a maximum temperature of $70^{\circ} \mathrm{C}$ and continued on a water bath at \pm $60^{\circ} \mathrm{C}$ until a thick extract $(100 \%$ concentration) is obtained which is then used for treatment. Then the test solution was prepared by dissolving liquid extract with $96 \%$ ethanol according to the treatment concentration of $25 \%, 50 \%, 75 \%$, and $100 \%$.

\section{Antibacterial Inhibition Test}

The test is carried out using the agar diffusion method (Kirby-Bauer), by using a petri dish which contains agar media and marking it for each positive and negative concentration and control. Paper disc is prepared on an empty petri dish and added to each test material and allowed to stand for approximately 2 hours. Staphylococcus epidermidis bacteria is scratched on the surface of the media so that it is evenly distributed. Paper discs on petri dishes are placed according to concentration and control markings. Incubate in an incubator at $37^{\circ} \mathrm{C}$ for 18-24 hours. Furthermore, inhibition zone observations will be made after 1 x 18-24 hours of the incubation period. A clear area is a sign of bacterial sensitivity to antibacterial used as test material. Measuring the diameter was done by calipers in millimeters by measuring the outer zone of the disc paper.

Inhibition zone measurement of Staphylococcus epidermidis bacteria from each treatment group was carried out after being incubated for 24 hours using calipers, then the measurement data were analyzed using a computer program.

Ethical clearance was issued by the Research Ethics Commission with the number 457/UN14.2.2.VII.14/LP/2019

\section{Result}

Inhibition zone measurement og Staphylococcus epidermidis bacteria can be seen in Figure 1 as follows.

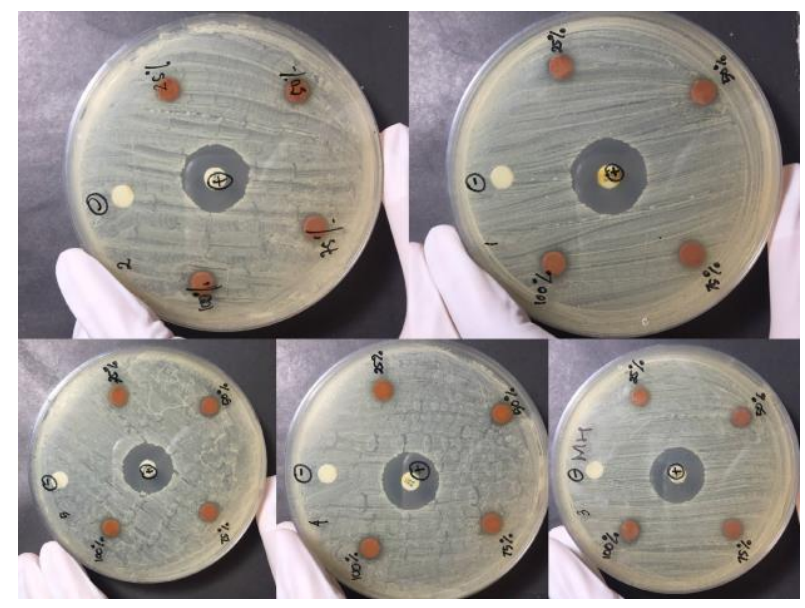

Figure 1. The Result Of Inhibition Zone Measurement

Based on the results of the normality test, Shapiro-Wilk test was performed and showed a significance values ( $p>0.05$ ) in all groups. That indicates data of this study are normally distributed. The Levene test showed a significance value of $p=0.028(p<0.05)$ in all treatment groups. It indicates data variance are significant differences or inhomogeneous data. The results showed normal and nonhomogeneous data distribution, the hypothesis test used is the one way anova parametric test.

The extract of temulawak rhizome in various concentrations has a significant effect on the growth of Staphylococcus epidermidis bacteria. One Way Anova test showed 
significance value $\mathrm{p}=0,000(\mathrm{p}<0.05)$. The results can be seen in Table 5.1 as follows.

Table 1. Results of Inhibition Zone Measurement of Antibacterial Test of Temulawak Rhizome Extract Against the Growth of Staphylococcus epidermidis Bacteria

\begin{tabular}{|c|c|c|c|c|c|c|}
\hline \multirow{2}{*}{$\begin{array}{l}\text { Treatment } \\
\text { Group }\end{array}$} & \multicolumn{5}{|c|}{$\begin{array}{l}\text { Inhibitory Zone } \\
\text { Diameter (mm) }\end{array}$} & \multirow{2}{*}{$\begin{array}{c}\text { Average } \\
\pm \text { STD } \\
(\mathrm{mm})\end{array}$} \\
\hline & I & II & III & IV & V & \\
\hline $\begin{array}{l}\mathrm{K} 1 \text { : Negative } \\
\text { Control }\end{array}$ & 0 & 0 & 0 & 0 & 0 & 0 \\
\hline $\begin{array}{l}\text { K2 : Positif } \\
\text { Control }\end{array}$ & 21 & 19 & 20 & 20 & 19 & $\begin{array}{c}19.80 \pm \\
0.83^{\mathrm{a}}\end{array}$ \\
\hline $\begin{array}{l}\text { P1 : Extract } \\
\text { Concentration } \\
25 \%\end{array}$ & 6 & 6 & 7 & 8 & 9 & $\begin{array}{c}7.20 \pm \\
1.30^{\mathrm{a}}\end{array}$ \\
\hline $\begin{array}{l}\text { P2 : Extract } \\
\text { Concentration } \\
50 \%\end{array}$ & 8 & 7 & 8 & 9 & 9 & $\begin{array}{c}8.20 \pm \\
0.83^{\mathrm{a}}\end{array}$ \\
\hline $\begin{array}{l}\text { P3 : Extract } \\
\text { Concentration } \\
75 \%\end{array}$ & 8 & 9 & 8 & 9 & 10 & $\begin{array}{c}8.80 \pm \\
0.83^{\mathrm{a}}\end{array}$ \\
\hline $\begin{array}{l}\mathrm{P} 4: \text { Extract } \\
\text { Concentration } \\
100 \%\end{array}$ & 8 & 9 & 10 & 10 & 9 & $\begin{array}{c}9.20 \pm \\
0.83^{\mathrm{a}}\end{array}$ \\
\hline
\end{tabular}

Note: Superscript letter a in the same column shows significant differences $(p<0.05)$

Temulawak rhizome extract showed the greatest inhibition at $100 \%$ concentration with an average inhibition zone diameter of 9.20 $\mathrm{mm}$. It can be concluded that the greatest inhibitory power was found in temulawak rhizome extract with a concentration of $100 \%$. Temulawak rhizome extract showed an inhibitory activity at $25 \%$ concentration with an average inhibition zone diameter of 7,20 $\mathrm{mm}$. The average yield of inhibition zone diameters in each treatment group can be described in the diagram as follows.

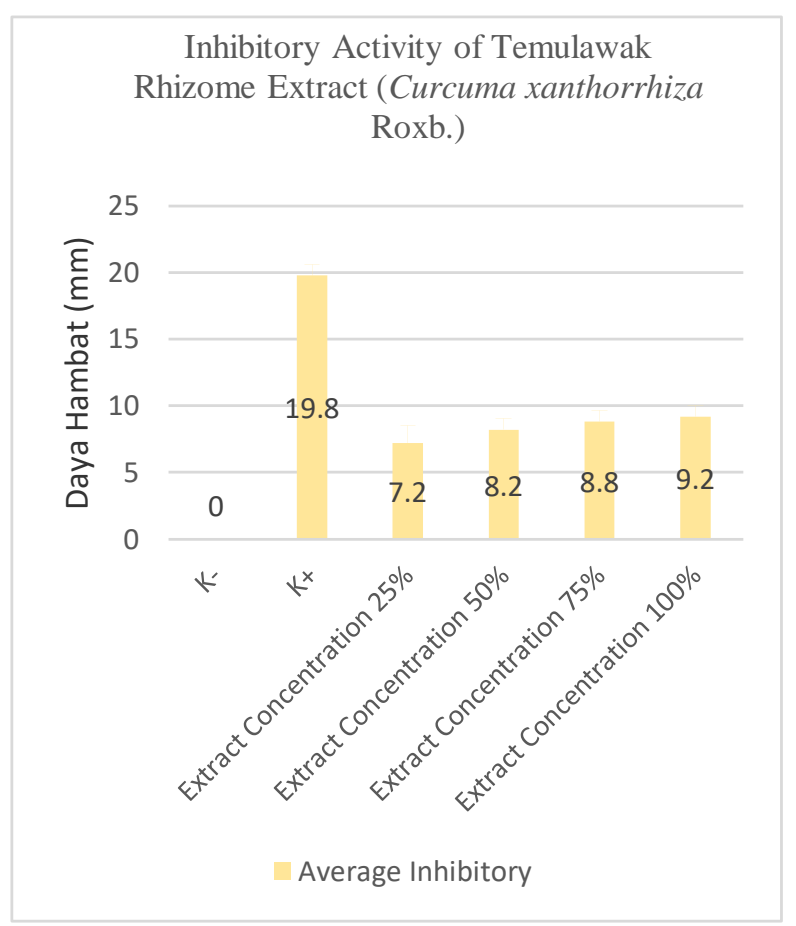

Figure 2. Inhibitory Activity of Temulawak Rhizome Extract Againts Staphylococcus epidermidis Growth

Based on the diagram in Figure 1 showed that the greater concentration of temulawak rhizome extract resulted the wider average diameter of the Staphylococcus epidermidis growth inhibition zone that was formed or concentration-dependent. It can be concluded that there was a direct correlation between the concentration of temulawak (Curcuma xanthorhiza Roxb.) extract with the average diameter of the growth inhibition zone. The positive control group used vancomycin which have higher inhibitory power than the extract concentration group.

\section{Discussion}

The results showed extract of temulawak rhizome (Curcuma xanthorhiza Roxb.) with four variations of concentration had an average inhibition zone diameter ranging from $7 \mathrm{~mm}$ $9 \mathrm{~mm}$. According to Davis and Stout, 1971 in previous studies were classified as a medium inhibitory zone response to the growth of the bacterium Staphylococcus epidermidis. ${ }^{10}$

The results showed that the temulawak rhizome extract with a concentration of $100 \%$ have the greatest inhibition which is seen based on the diameter of the inhibitory zone. The 
higher concentration of temulawak rhizome extract, the greater ability to inhibit bacterial growth. This is following the explanation of Pelezar and Chan, 1998 that several things affect the performance of antibacterial substances including the concentration of antibacterial substances, the content of antibacterial compounds, the number of microorganisms, the temperature and the $\mathrm{pH}$ level. In addition to the concentration of the substance, the compound content in the temulawak rhizome extract can also influence the antibacterial activity in this study. ${ }^{7}$

Antibacterial effect of temulawak rhizome extract against the growth of Staphylococcus epidermidis bacteria is suspected due to secondary metabolite components contained in temulawak rhizome. ${ }^{8}$ The temulawak rhizome contains active compounds in the form of essential oils, curcumin, alkaloids, flavonoids, terpenoids, phenols and tannins which are the result of secondary metabolites of plants.$^{9}$

Curcumin and xanthorrhizol compounds are the main components in the temulawak rhizome which have a broad spectrum as active antibacterials against gram-positive and gramnegative bacteria. The curcumin works by inhibiting cell proliferation and working on cell walls or bacterial cell membranes by changing the permeability of bacterial cells. ${ }^{11}$ The transport of substances into cells and outside cells becomes uncontrolled. Substances in cells such as organic ions, enzymes, amino acids, and nutrients can leave the cell. When enzymes leave the cell together with substances such as water and nutrients can cause inhibited metabolism resulting in decreased ATP needed for cell growth and proliferation, furthermore bacterial cell growth is inhibited and causes cell death. ${ }^{12}$ Antibacterial activity of curcumin is known by inhibiting FtsZ protein which results in disruption of Z-ring formation thereby inhibiting bacterial cell division. ${ }^{13}$ Also, curcumin is known to have a phototoxic effect on bacteria where when exposed to light the curcumin will produce hydrogen peroxide which can damage bacterial cytoplasmic membranes. $^{7}$

Also, the essential oil content in the form of phenols and terpenoids can inhibit bacteria by damaging the cytoplasmic membrane of the bacterium. ${ }^{11}$ The content of tannin compounds also acts as a growth inhibitor so that it can inhibit the growth of microorganisms. Flavonoid compounds in the temulawak rhizome are known to have the ability to damage cell walls and inhibit the formation of proteins that inhibit bacterial growth. As well as the content of alkaloids in temulawak can interfere with the preparation of peptidoglycan on bacteria so that the bacterial cell wall layer becomes unstable. ${ }^{7,11}$

Other factors that influence the results of the study are biological factors including plant species, location of harvest, time of harvest, storage of plant material, age of plants and parts used. ${ }^{14}$ The location of growth is related to the height of the growing site which is strongly influenced by local climatic conditions. Besides, the age of the plant also affects the content of xanthorrhizol which is an active compound in the temulawak rhizome. The study of Khaerana, 2008 the content of xanthorrhizol in the temulawak rhizome will be higher at the age of the crop harvest above seven months compared to the age of the harvest five months. ${ }^{15}$

This research is in line with research conducted by Ngadino, 2018, namely temulawak extract with $96 \%$ ethanol solvent capable of inhibiting the growth of Mycobacterium tuberculosis H37Rv bacteria in vitro using the disc diffusion method and broth microdilution. ${ }^{11}$ Other research conducted by Purnamaningsih, 2017, which tested temulawak extract antibacterial test on the growth of pathogenic bacteria E. coli ATCC 11229 and Staphylococcus aureus ATCC 25923.16 Another study was conducted by Mashita, 2017 which tested the antimicrobial effects of $96 \%$ temulawak rhizome extract (Curcuma xanthorrhiza Roxb.) on the growth of Staphylococcus aureus. ${ }^{7}$

The difference in the results of the inhibition zone diameter formed by the antibacterial activity of the temulawak rhizome extract in the above study could have occurred due to differences in the bacterial species and the solvent fraction used. In this study using Staphylococcus epidermidis while in the research that conducted by Mashita, 2017 was used Staphylococcus aureus bacteria. Although 
the two bacteria belong to the class of grampositive bacteria, between $S$. aureus and S.epidermidis have differences where the S. epidermidis bacteria is a strain that is resistant to antimicrobials, so to inhibit its growth, it is necessary to antimicrobial against the more sensitive bacteria. ${ }^{17}$ In a study by Ngadino, 2018 using the Mycobacterium tuberculosis H37Rv bacteria while the research by Purnamaningsih, 2017 used gram-negative bacteria namely $E$. coli bacteria which tend to be difficult to be penetrated by antibacterial substances. ${ }^{11,16}$

However, the ability of temulawak rhizome extract as an antibacterial based on the results of this study is still lower than the antibiotics tested in this study which is vancomycin $30 \mu \mathrm{g}$. Vancomycin antibiotics can produce an average inhibition zone diameter of $19.80 \mathrm{~mm}$. This can occur because of temulawak rhizome crude extract which is dose-dependent has a smaller dose than vancomycin antibiotics. Thus, the content of antibacterial compounds in temulawak rhizome will be less than the content of antibacterial compounds in vancomycin which affects inhibitory ability. ${ }^{18}$ Also, this can occur because vancomycin with temulawak extract has a different way of working, namely vancomycin works bactericide while the temulawak extract is suspected to be bacteriostatic. ${ }^{7}$

\section{Conclusions}

Based on this research, it can be concluded that the $96 \%$ ethanol extract of temulawak rhizome (Curcuma xanthorrhiza Roxb.) has an inhibitory effect on the growth of Staphylococcus epidermidis bacteria. Ethanol extract $96 \%$ of temulawak rhizome (Curcuma xanthorrhiza Roxb.) had significant inhibitory differences in each concentration group. The temulawak rhizome extract concentration of $25 \%$ has been able to inhibit the growth of Staphylococcus epidermidis bacteria and the greatest inhibitory response lies in temulawak rhizome extract with a concentration of $100 \%$. This research illustrates that the active substance in temulawak can be useful for the treatment of antibiotics in the future.

\section{Acknowledgement}

The researcher would like to thank profusely to Prof. Dr. dr. I Made Jawi, M. Kes, Dr. dr. Agung Wiwiek Indrayani, M.Kes, Desak Ketut Ernawati, S.Si, Apt, PGPharm, Mpharm, dr Ni Wayan Sucindra Dewi, M.Biomed for their guidance and support to complete this research as graduate graduation.

\section{References}

1. Anjos LM, Marcondes MB, Lima MF, Mondelli AL, Okoshi MP. 2014. Streptococcal acute pharyngitis. Revista da Sociedade Brasileira de Medicina Tropical. 47 (4): 409-413.

2. Movita T. 2013. Acne Vulgaris - Clinical Aspects. Continuing Medical Education Journal - 203. 40 (4): 269-272

3. Pinheiro L, Brito CI, de Oliveira A, Martins PY, Pereira VC, da Cunha Mde L. 2015. Staphylococcus epidermidis and Staphylococcus haemolyticus: Molecular Detection of Cytotoxin and Enterotoxin Genes. Toxins. 7: 3688-3699.

4. Lieve M, Shahrooei M, Hofmans D, Eldere JV. 2012. Immunoprophylaxis and immunotheraphy of Staphylococcus epidermidis infections: challenges and prospects. Expert Rev. Vaccines. 11 (3): 319-334

5. Salea R, Edward W, Bambang Veriansyah, and Raymond R. 2014. Optimizing oil and xanthorrhizol extraction from Curcuma xanthorrhiza Roxb. Rhizome by supercritical carbon dioxide. J Food Sci Technol. 51 (9): 2197 2203

6. Leite B, Gomes F, Teixera P, Pizzolitto E, Olivia CW, Oliveira R. 2011. In vitro Activity of Daptomycin, Linezolid and Rifampicin on Staphylococcus epidermidis Biofilms. Curr Microbiol. 63:313-317

7. Mashita, A. 2017. Efek Antimikroba Ekstrak Rimpang Temulawak (Curcuma xanthorrhiza) Terhadap Pertumbuhan Staphylococcus Aureus. Saintika Medika. 10(2): 138. 
8. Mekni MA, Achour W, Ben HA. 2017. Overview of Genetic Background Beyond Polysaccharide Intercellular Adhesion Production in Staphylococcus epidermidis. Jundishapur J Microbiol. 10 (1): 2-12.

9. Dermawaty, D. E. 2015. Potential Extract Curcuma ( Curcuma Xanthorrizal , Roxb ) As Antibacterial. Majority. 4 :5-11.

10. Amalia, R. And Sari, R. 2017. Penentuan Nilai FICI Kombinasi Ekstrak Kulit Daun Lidah Buaya (Aloe Vera (L.) Burm. F.) Dan Gentamisin Sulfat Terhadap Bakteri Staphylococcus Aureus. Traditional Medicine Journal. 22 (3) : 175-181.

11. Ngadino, Setiawan, Koerniasari, Ernawati, Sudjarwo SA. 2018. Evaluation of antimicrobacterial activity of Curcuma xanthorrhiza ethanolic extract against Mycoacterium tuberculosis $\mathrm{H} 37 \mathrm{Rv}$ in vitro. Veterinary world. 11(3): 368-372

12. Suhartati, R. 2018. Aktivitas Antibakteri Ekstrak Etanol Kulit Buah Naga Merah (Hylocereus Polyrhizus) Terhadap Bakteri Streptococcus Pyogenes. Jurnal Kesehatan Bakti Tunas Husada: Jurnal Ilmu-Ilmu Keperawatan. Analis Kesehatan Dan Farmasi. 17(2) : 513.

13. Rekik A. 2012. Anti-inflammatory and Antimicrobial Effects of Heatclearing Chinese Herbs: A Current Review. Journal of Traditional and Complementary Medicine. 4(2): 93-98
14. Suswati, I. 2017. Efek Ekstrak Daun Sirih Merah (Piper Crocatum Ruiz \& Pav) Terhadap Pertumbuhan (Streptococcus Pneumoniae). Saintika Medika. 8(1) : 1-5.

15. Khaerana. 2008. Pengaruh Cekaman Kekeringan Dan Umur Panen Terhadap Pertumbuhan Dan Kandungan Xanthorrhizol Temulawak (Curcuma xanthorrhiza Roxb.). Pengaruh Cekaman Kekeringan Dan Umur Panen Terhadap Pertumbuhan Dan Kandungan Xanthorrhizol Temulawak (Curcuma xanthorrhiza Roxb.). 36(3) : 241-247.

16. Purnamaningsih, N. 2017. Uji Aktivitas Antibakteri Ekstrak Temulawak (Curcuma xanthorrhiza) Terhadap Bakteri Escherichia Coli ATCC 11229 Dan Staphylococcus Aureus ATCC 25923. Jurnal Penelitian Saintek. 22(2) : 140 147.

17. Jawetz, E., Melnick, J. L., Adelberg, E. A. 2008. Medical microbiology. Jakarta: Salemba Medika.

18. Suhartati, R. 2018. Aktivitas Antibakteri Ekstrak Etanol Kulit Buah Naga Merah (Hylocereus Polyrhizus) Terhadap Bakteri Streptococcus Pyogenes. Jurnal Kesehatan Bakti Tunas Husada: Jurnal Ilmu-Ilmu Keperawatan. Analis Kesehatan Dan Farmasi. 17(2) : 513. 